\title{
The Human Rights Act 1998: Article 8 case law and child and adolescent mental health services
}

\author{
Martin Curtice \& Tim Hawkins
}

\begin{abstract}
SUMMARY
The United Nations' 1959 Declaration of the Rights of the Child states that 'the child, by reason of his physical and mental immaturity, needs special safeguards and care, including appropriate legal protection, before as well as after birth'. In the UK, children and young people are afforded protection by two important pieces of legislation: the UN Convention on the Rights of the Child and the Human Rights Act 1998. There have been plentiful and varied challenges involving children and young people, in particular under Article 8 of the Human Rights Act. This review of Article 8 cases demonstrates both its use and key principles underpinning its use.
\end{abstract}

\section{DECLARATION OF INTEREST}

None.

The Human Rights Act 1998 enacts most of the European Convention on Human Rights into UK legislation and sets out fundamental rights that all people are entitled to enjoy. Article 8 of the Act in particular applies to children and young people by providing for the right to respect for private and family life, home and correspondence:

(1) Everyone has the right to respect for his private and family life, his home and his correspondence.

(2) There shall be no interference by a public authority with the exercise of this right except such as is in accordance with the law and is necessary in a democratic society in the interests of national security, public safety or the economic well-being of the country, for the prevention of disorder or crime, for the protection of health or morals, or for the protection of the rights and freedoms of others.

Courts will first assess whether Article 8(1) is engaged, i.e. does the infringement pertain to private and family life, home and correspondence. If it is, Article 8(2), which sets out the exceptions in which interference with the right may be permitted, will then be analysed. Under Article 8(2), before interference with the right is permitted, it must be:

- 'in accordance with the law';

- 'necessary in a democratic society'; and

- in pursuit of one of the specified objectives or aims.
This article reviews case law relating to Article 8 and children and young people with respect to family life, confidentiality and duty of care.

\section{Family life}

\section{Nielsen v. Denmark (1988)}

This case, involving a 12-year-old boy being placed in psychiatric care by his mother, produced a useful definition of family life:

family life... incorporates a broad range of parental rights and responsibilities in regard to the care and custody of minor children. The care and upbringing of children normally and necessarily require that the parents or an only parent decide where the child must reside and also impose, or authorise others to impose, various restrictions on the child's liberty... Family life in this sense, and especially the rights of parents to exercise parental authority over their children, having due regard to their corresponding parental responsibilities is reconsidered... in particular by Article $8 \ldots$ the exercise of parental rights constitutes a fundamental element of family life.

Treharne $\mathcal{E}$ Ors v. Secretary of State for Work $\mathcal{E}$ Pensions [2008] expanded on the essence of family life and included the 'love, trust, confidence, mutual dependence and unconstrained social intercourse' that exists within a family.

\section{Sheffield City Council v. (1) S (by his litigation friend the Official Solicitor) (2) DS [2002]}

This case considered whether a mentally incapacitated young man should live with his father or under the care of the local authority. The judgment provided pertinent points concerning the scope of Article 8 in such cases:

- 'family life' continues 'after a child has reached the age of majority and even after emancipation';

- 'private life' includes at least two elements: an 'inner circle' within which the individual may live his own personal life as he chooses and a 'right to establish and develop relationships with other human beings';

- private life and family life may come into conflict;

- a father's Article 8 rights cannot be a 'trump card'; they must be "weighed and assessed in the balance against his son's Article 8 rights'; and
Martin Curtice is a consultant in old age psychiatry. He obtained a Master of Laws with Distinction in Mental Health Law in 2003 and has an interest in mental health law and the Human Rights Act. He sits on the Royal College of Psychiatrists' Special Committee on Human Rights. Tim Hawkins is a consultant in child and adolescent psychiatry. He works in a dedicated adolescent service providing out-patient, day-patient and in-patient services. His particular areas of interest include risk management in adolescents and the legal basis for treatment. Correspondence Dr Martin Curtice, Consultant in Old Age Psychiatry, Hollyhill Unit, Rubery Lane, Rubery, Birmingham B45 9AY, UK.Email: mjrc@ukonline.co.uk 
- where there is conflict 'in the final analysis, parental rights have to give way to the child's ... the answer can be no different where the child, although now an adult, remains unemancipated because mentally incapacitated'.

The final point has been firmly established in case law: in any case where the Article 8 rights of parents and those of a child are at stake, the child's rights must be the paramount consideration; in any balancing of interests, the interests of the child must prevail (Elsholz v. Germany 2000; TP and KM v. The United Kingdom 2001; Yousef v. The Netherlands 2002).

\section{(1) Ingo Kutzner (2) Annette Kutzner v. Germany (2002)}

In this case the applicants complained of violation of Article 8 on the grounds that the removal of their parental rights and the placement of their daughters into foster care (they were placed in separate, unidentified foster homes), with severe contact restrictions, had interfered with their right to a family life. The applicants' children were placed into care because of social services' concerns that: (a) the applicants lacked the intellectual capacity to bring up their children; (b) the children were not developing mentally and physically as quickly as would be expected; and (c) the applicants had not cooperated with social services. The European Court held that Article 8 was violated because the measures taken had not met the positive duty to facilitate family reunification and had been disproportionate to the legitimate aim pursued and only served to alienate the children from the parents. Disproportionately severe contact restrictions, on communications by written correspondence and telephone, with a child in care have also been found to violate Article 8 (Andersson v. Sweden 1992).

\section{$\operatorname{Re} R$ (A child) [2003]}

In this case the Court of Appeal analysed whether the former partner of a woman who became pregnant through in vitro fertilisation (IVF) should be the child's legal father. The partner had no genetic link with the child because she was conceived through the use of donor sperm. Initially, the woman and her partner had been 'treated together' under the terms of the Human Fertilisation and Embryology Act 1990, which would ordinarily give the partner legal fatherhood. At the time of the successful IVF cycle the couple had separated without telling the clinic.

The Court concluded that the partner should not be regarded as the child's legal father because the couple were no longer being 'treated together' at the key point when the embryo was transferred successfully into the woman's womb. The Court made reference to the scope of 'family life':

There is no 'family life' between the child and ... the former partner ... which is entitled to respect under Article 8(1). Family life does not inevitably flow from genetic fatherhood (or parenthood), although it often will. It may flow from looking after a child to whom one is not related by blood, but the length and intensity of that relationship will be particularly relevant. Where there is neither a genetic link nor a personal relationship of a family nature, there is no family life to respect.

\section{RK and AK v. The United Kingdom (2008)}

The applicants were the parents of a baby daughter. At 2 months old the baby was taken to hospital having screamed out in pain while being handled. The confusion as to the actual mechanism of injury was made worse by language difficulties with the mother and grandmother. An X-ray revealed a fracture of the femur. It was concluded that the injury was most likely non-accidental. A subsequent child protection conference sought a second opinion while obtaining an interim care order. The baby was discharged into the care of her aunt and the parents were allowed supervised contact. The baby sustained a second injury in her aunt's care and bilateral femoral fractures were found; subsequently osteogenesis imperfecta ('brittle bone disease') was diagnosed. Two medical second opinions concluded that there were no obvious grounds for reaching the diagnosis (a rare diagnosis) in preference to nonaccidental injury when the baby first presented. The care order was subsequently discharged and the baby returned to her parents.

The Court confirmed that the interim care order resulting in the baby being placed away from the parents constituted an interference with Article 8(1). The Court further considered under Article 8(2) that such interference was both 'in accordance with the law' and 'necessary in a democratic society'. In arriving at this conclusion, the Court opined that it was not called upon to adjudicate, retrospectively, as to the best medical practice or the most reliable expert opinion. It was satisfied that there were 'relevant and sufficient' reasons for the authorities to take protective measures, such measures being proportionate in the circumstances to the aim of protecting the baby. Article 8 was therefore not breached. The Court commented that mistaken judgments or assessments by professionals do not per se render childcare measures incompatible with the requirements of Article 8. The authorities, medical and social, have duties to protect children and cannot be held liable every time genuine and reasonably held concerns about the safety of children vis-à-vis members of their families are proved, retrospectively, to have been misguided. 


\section{Confidentiality}

\section{$R$ (on the application of TB) $v$. The Combined Court at Stafford and (1) The Crown Prosecution Service and (2) South Staffordshire Healthcare NHS Trust [2006]}

This case concerned the confidentiality of a 15-yearold girl's medical notes. The girl was the victim of an alleged sexual attack. The alleged attacker sought disclosure of her medical notes with the intention of undermining her credibility as a witness by reference to her psychiatric history. In Court, the trust that was caring for her was represented, but she was not. The applicant argued that she should have been informed of the application for disclosure of her notes and given the opportunity to make representation herself.

In finding that Article 8 was breached the Court noted that:

- the confidentiality of a patient's notes belongs to the patient;

- breaching that confidentiality would interfere with the patient's Article 8(1) rights and could only be lawful if justified under Article 8(2);

- under Article 8(2) the failure to notify the applicant was not in accordance with domestic law; and

- Article 8 includes implicit procedural requirements: interference with a person's rights to respect for their private and family life cannot be considered to be 'necessary' if that person has not been appropriately involved in the relevant decision.

\section{W v. (1) Westminster City Council (2) Anca Marks (3) James Thomas [2005]}

This case concerned allegations of libel, resulting from concerns expressed in a social worker's report produced for a child protection conference, that 'W' might be grooming a child for prostitution. The report was 'published' to the child's mother, W and four social care professionals.

The local council accepted that the words were defamatory and such concerns should not have been included in the report without having been raised first withW (it was later accepted by the council that the concerns had been misplaced and there was no evidence to substantiate them). The council argued that, because the communications were made at a child protection conference, they were covered by qualified privilege.

The judge held that the inclusion of the concerns in the report was an honest mistake and not a reckless or malicious action. He also held that the communications were protected by qualified privilege and rejected W's claim of libel. He analysed the claim under Article 8 and opined that:
- although the claim in libel had failed because of the defence of qualified privilege, this did not mean that a claim under the Human Rights Act must also fail;

- the 'misuse of personal information by a local authority in perfect good faith' could be a breach of Article 8;

- a breach of Article 8 could be committed unwittingly. However, it was not necessary to demonstrate either carelessness or bad faith for there to be liability under the Human Rights Act;

- the disclosure of concerns about W at the child protection conference did constitute an interference with W's Article 8 rights and W's reputation suffered because of this; hence, Article 8 was breached; and

- the disclosure was not at the 'higher end of possible gravity'. Given that prompt action had been taken by the council to establish what had gone wrong, to offer an apology and to issue a correction to the child protection conference report, nothing more was required by way of monetary compensation to afford 'just satisfaction' to $\mathrm{W}$.

\section{Samuel $R$ (by his Grandmother and Litigation Friend June Margaret D) v. W Primary Care Trust [2004]}

This case involved the consideration of competing Article 8 rights and involved a child with Asperger's syndrome who lived with his grandmother (who brought the action on his behalf). It concerned the extent to which it was permissible for a primary care trust to disclose confidential material about the treatment of the child to his grandmother in connection with a possible negligence claim (the child had consented to therapy on the basis that it was private but believed that the therapist had discussed his case with others). The child's notes, however, included sensitive information about his mother, disclosure of which would potentially breach her Article 8 rights.

In balancing the competing interests, the judge allowed limited disclosure of the child's medical notes to his grandmother in connection with a possible negligence claim. However, the Article 8 rights of the child and his mother to privacy required conditions to be placed on the disclosure:

- the child should not be informed of the details of the disclosed documents;

- disclosure should only be to medical and legal advisers and the grandmother; and

- there should be no disclosure, however, to the grandmother of information relating to the mother that was not relevant to the issues pertaining to her grandson's claim. 
A local authority v. (1) A health authority (2) Ms A [2003]

This case involved the proposed publication of a report commissioned by a local area child protection committee as a result of care proceedings taken by the local authority in respect of six children and a foster home. Investigations into the care of some of the children then living with the foster mother led the police and social services to remove 12 children. The foster mother, the children and vulnerable adults living with the foster mother objected to publication of the report, as did the local National Health Service trust. In assessing whether the report could be published, the judge had to balance the competing interests of different parties and also differing Convention rights of each party, that is, the Article 8 rights of the children $v$. the Article 10 rights (the right to freedom of expression) of the Committee to publish the report.

The Court opined that the local authority was entitled to publish the report unless the publication would be so disadvantageous to the children that the court was driven to restrain publication in whole or in part. The balancing exercise came down in favour of protection of the children, their welfare being of paramount importance, and an injunction was granted restraining publication (i.e. the Article 8 rights of the children and the vulnerable people outweighed the authority's Article 10 rights).

\section{Duty of care}

\section{TP and KM v. The United Kingdom (2001)}

In this case concerning child sexual abuse the Court found that Article 8 places a duty on local authorities to involve parents appropriately in decisions affecting their children's care. It concluded that a local authority had acted proportionately both in removing a child from her home and placing her in foster care for a year. However, the authority breached both the child's and the mother's rights under Article 8 in failing to involve the mother appropriately in the decision-making process. In particular, the fact that the mother was not able to see a video of an interview in which her child identified the abuser may have contributed to the misidentification of the abuser. The Court emphasised that whereas there may be cases where such videos should not be disclosed (e.g. where disclosure would put the child at risk), 'crucial consideration' should always be given to their disclosure and the local authority erred in this case in not submitting the issue to Court for determination.

\section{Venema v. The Netherlands (2002)}

This case concerned the separation of a baby from her parents for more than 5 months because of concerns, later shown to be mistaken, that the mother might be experiencing Munchausen syndrome by proxy. The parents were not involved in the decision to remove their child. They only discovered that a court order had been made after they arrived at hospital to pick up the baby after treatment.

It was accepted that the decision to place the baby in foster care breached the rights of both parents and child under Article 8(1). It was also accepted that the proceedings were in accordance with domestic law and they pursued the 'legitimate aim' of protecting the child's rights. The deciding issue was whether the actions of the authorities had been 'necessary in a democratic society'. The court concluded that such actions were not, and hence Article 8 was breached because the interference could not be justified under Article 8(2).

With regard to Article 8 the Court noted:

- parents should be involved in the decision-making process 'to a degree sufficient to provide them with the requisite protection of their interests';

- parents must also be able to obtain access to information that is relied upon by the authorities when taking protective measures in connection with their child; and

- whereas there may be circumstances when a child has to be removed in an emergency without involving his or her parents in the decision-making process, the state must be able to demonstrate that such a measure was genuinely necessary, that a careful assessment of the effect of the proposed measure on both parents and child had been made, and that possible alternatives had been considered.

A UK case (Re C (A child) 2007) similarly found that the insufficient involvement of the parent in a local authority's decision-making process breached a young mother's Article 8 rights. The authority failed to involve her in a meeting where it was decided to abandon her existing care plan. The care plan aimed to support her in looking after her baby herself, but included preparation for adoption should this prove impossible; abandoning the care plan essentially meant the permanent removal of the baby from the mother.

\section{JD (FC) (Appellant) v. East Berkshire Community Health NHS Trust and others (Respondents) and two other actions (FC) [2005]}

In this judgment the House of Lords confirmed that health professionals do not owe a common-law duty of care to parents when suspecting parents of abusing their child. The accusations were proved to be unfounded and the parents sought damages due to the false accusations having caused psychiatric harm. 
The Court of Appeal had held that, in some circumstances, health professionals will owe a duty of care to a child when investigating suspicions of child abuse (and hence could be sued if the child suffered as a result of negligence in the way the health professionals carried out their duties). The Court rejected arguments by the parents that a duty of care was also owed to them, primarily because in cases of abuse children's and parents' interests were directly in conflict. It would not, therefore, be appropriate to impose a duty on the health professional towards the parents in addition to their duty towards the child.

On appeal at the House of Lords the parents contended that the suggested duty of care to the parent was the same as to the child. The House of Lords upheld the Court of Appeal decision that the danger of conflict of interest was such that it was inappropriate to impose a duty on health professionals towards the parents of children in such circumstances. In arriving at this decision, their Lordships considered Article 8 rights of the parents:

Public authorities should, so far as possible, cooperate with the parents when making decisions about their children. Public authorities should disclose matters relied upon by them as justifying interference with family life. Parents should be involved in the decision-making process to whatever extent is appropriate to protect their interests adequately.

However, the parents failed to demonstrate that the right to respect for family life under Article 8 was so strong as to impose a duty of care in respect of parents suspected of abusing their children, that is, interference with family life did not justify according a suspected parent a higher level of protection than other suspected perpetrators such as teachers and childminders.

BOX 1 Core Article 8 principles

Article 8 is a qualified right (others being 'absolute' or 'limited'): there are qualifying statements regarding its use embedded within its definition. Interference with these rights is permissible only if what is done has a basis in law. There is an emphasis on the need to balance private and public interest.

The main aim of Article 8 is to protect the individual against arbitrary interference by the public authorities, but in doing so to strike a fair balance between the interests of the individual and the interests of the community as a whole.

\section{Article 8 engagement: the Court will firstly} assess whether paragraph 1 applies and if it does then Article 8 will be engaged and the paragraph 2 components will be analysed to assess whether the Article has been violated.

Article 8(2) violations: there will be a violation unless the three criteria are met: the interference must be (1) in accordance with the law;

(2) necessary in a democratic society; and (3) in pursuit of one of the specified objectives. The onus is on the State to establish that these are met, otherwise there will be a breach.

In accordance with the law: this is a threepronged notion: (1) there must be a specific legal rule or regime that authorises the interference; (2) the citizen must have adequate access to the law in question; and (3) domestic law must be adequately accessible and formulated so that it is reasonably foreseeable and there must be adequate and effective safeguards in that law to protect against arbitrary interference. The need for flexibility and discretion is also recognised.
Necessary in a democratic society: this is a two-pronged notion and implies: (1) that an interference corresponds to a pressing social need; and (2) that it is proportionate to the legitimate aim pursued. The reasons for the interference must be 'relevant and sufficient'. The more serious the intervention, the more compelling must be the justification (i.e. a sliding scale).

In pursuit of one of the specified objectives or aims: there will be a breach of Article 8 unless the State establishes that the following criteria, as set out in 8(2), are met:

There shall be no interference by a public authority with the exercise of this right except such as is in accordance with the law and is necessary in a democratic society in the interests of national security, public safety or the economic well-being of the country, for the prevention of disorder or crime, for the protection of health or morals, or for the protection of the rights and freedoms of others.

This means that interference must be justified by one of the exceptions and must be the minimum necessary to obtain the legitimate aims.

Proportionality: clinical intervention needs to balance the severity of the effect of the intervention with the severity of the presenting clinical problem (i.e. be a proportionate response to a clinical scenario)

Proportional interference: when considering whether an interference with a Convention right is proportionate, the burden lies on the State to justify its action. The interference must go no further than is strictly necessary to achieve its permitted purpose; the more substantial the interference the more that is required to justify it (i.e. a sliding scale approach to its use).

Proportionality 'test' for the use of Article 8: (1) what is the 'interest' that is relied on? (i.e. private and family life, home and correspondence); (2) does the interest correspond to a pressing social need? (3) is the interference proportionate to the interest? and (4) are the reasons given by the authorities relevant and sufficient?

Margin of appreciation: domestic States have different accepted clinical practices and standards, hence the margin of appreciation is accepted as being very wide to reflect this. Therefore, clinical decisions that are proportional, therapeutically necessary and in keeping with accepted clinical practice are very unlikely to be outside this margin.

Private life: this concept covers the right to develop one's own personality and to create relationships with others. It contains both positive and negative aspects.

Positive obligations: the State has an obligation to provide for an effective respect for private life.

Negative obligations: the State should refrain from interference with a private life.

Article 8 spectrum of infringements: In reflecting the dynamic nature of Article 8 being underpinned by the concept of proportionality, the Court has suggested that there can be a 'spectrum' of human rights infringements (i.e. Article 8 violations can be placed on a spectrum of seriousness of infringement). This has implications when Courts consider the extent of financial compensation (i.e. less compensation for less severe violations). 
London Borough of Brent v. (1) Mr and Mrs N, the minor's foster carers and (2) $P$, a minor (appearing by Pauline Bennett, her Guardian) [2005]

In this case the High Court assessed whether a local authority was duty bound to inform a child's father that the foster carer was HIV-positive. The foster carer had objected to this information being revealed.

In reviewing previous jurisprudence on the disclosure of highly personal information, the judge pertinently noted that 'disclosure should only be made where there is a pressing need for that disclosure' and there was 'an obligation on a Local Authority to share relevant information relating to a child in their care with its parents', that 'relevant information would include the state of the child's health' and that 'a child's health covers exposure to infectious diseases where the risk is not negligible and the consequence of an infection serious', that is where the principle of proportionality applied.

In this case, however, there was no duty on the local authority to inform the parents given that there was 'sound medical evidence that the risk of infection is negligible'. In applying the Human Rights Act the Court concluded that:

- disclosure impinged on the foster carer's right to respect for his private life, i.e. Article 8 rights;

- it would be in breach of the duty owed to the foster carer to disclose confidential details relating to his health;

- there was no need for such disclosure - the rights of the mother and father to know of any risk to which their child might be exposed while in care does not arise where the risk is negligible, and the disclosure is opposed. Serious reasons were required and in this case they had not been established; and

- conversely, where the risk is not negligible the duty to disclose may overcome the foster carer's rights and the duty owed to him. Each case will be dependent on its own facts.

\section{Mrs Stephanie Lawrence v. Pembrokeshire County Council [2006]}

This case, where children had been inappropriately placed on the child protection register, concurred with the Justice Department's decision and again concluded that health and social care professionals do not owe a common-law duty of care to parents in cases of suspected child abuse. They should be able to focus fully on the interests of the child, without having to worry about the interests of the parent, interests that would be diametrically opposed in a genuine case of abuse.
The judge concluded by suggesting that parents' rights under Article 8 and the existing English common law restricting any duty of care to parents in such cases could be brought into harmony by adopting the approach that any child protection measures taken as a result of an honest but mistaken belief in parental abuse would be 'necessary in a democratic society' and hence any interference with family life could be justified under Article 8(2).

\section{Discussion}

These cases demonstrate core Human Rights Act principles that underpin the application of Article 8 (Box 1) and specific Article 8 issues relating to children and younger people (Box 2). The most important of these for clinical use are proportionality and margin of appreciation.

Because Article 8 is underpinned by proportionality it will continue to be one of the most broadly interpreted provisions of the Human Rights Act and will apply in myriad situations. In regards to children and young people, further examples of the diverse use of Article 8 include:

- surgery for conjoined twins (Re A (Children), 2000)

- end-of-life and palliative care (Glass v. United Kingdom 2004)

- child maintenance payments (Treharne 2008)

- childhood immunisations (Re C \& F 2003)

- abortion (Vo v. France 2004)

- emergency removal of newborn babies into care (Bury Metropolitan Borough Council v. D 2009)

- review of the Department of Health's guidance on sexual health matters for young people $(R$ (Sue Axon) 2006)

- anonymity on TV (Z County Council 2008).

A review of Article 8 adult case law in this journal (Curtice 2009) described issues that may pertain to children and young people, including: personal care being provided by same-sex staff; the use of manual or hoisting equipment for disabled people; an unacceptable delay in providing suitable accommodation for a severely disabled woman and her family; and the closure of day centres and care homes.

The government is required to report to the UN Committee on the Rights of the Child on how it is fulfilling its human rights obligations to children and young people. Its most recent report (HM Government 2007) describes how it has enabled a substantial body of legislation that serves further to enshrine in law the well-being of children. The most important is the Children Act 2004, which has provided the legal framework for Every Child Matters reforms in England 
(HM Government 2004). Other new UK legislation with an emphasis on human rights includes the Childcare Act 2006 and amendments to the Mental Health Act.

With regard to the 2007 amendments to the Mental Health Act, the Code of Practice(Department of Health 2008) explains the importance of establishing who has parental responsibility for a child or adolescent and introduces the concept of the 'zone of parental control'. The zone describes the limits of parental authority in providing consent on behalf of children and adolescents. The concept of a zone of parental control derives largely from European Convention on Human Rights case-law rulings. The process for assessing whether a particular decision falls within the zone is underpinned by proportionality and the margin of appreciation. This assessment has two key questions:

- Is the decision one that a parent would be expected to make, having regard both to what is considered to be normal practice in society and to any relevant human rights decisions taken by the courts?

- Are there any indications that the parent might not act in the best interests of the child or young person?

Implicit in this assessment is having knowledge of relevant human rights decisions and we hope that this, and similar articles, will add to such a knowledge base. It is likely that future Zone of parental control decisions will be liable to be challenged under Article 8.

BOX 2 Specific Article 8 issues relating to children and younger people

Competing Article 8 rights: cases may involve competing Article 8 rights between children and their parents or carers. In any case, where the Article 8 rights of parents and those of a child are at stake, the child's rights must be the paramount consideration; in any balancing of interests, the interests of the child must prevail.

Competing Convention rights: cases may involve competing interests of different parties and different Convention rights, e.g. Article 8 and Article 10 (the right to freedom of expression).

Family life: this does not inevitably flow from genetic parenthood, although it often will. It may flow from looking after a child to whom one is not related by blood, but the length and intensity of that relationship will be particularly relevant. Where there is neither a genetic link nor a personal relationship of a family nature, there is no family life to respect.

Private life: this includes at least two elements - an 'inner circle' within which the individual may live his own personal life as he chooses and a 'right to establish and develop relationships with other human beings'. Private life and family life may come into conflict.

Confidentiality: respecting the confidentiality of health data is a vital principle in the legal systems of all the contracting parties to the Convention. It is crucial not only to respect the sense of privacy of a patient, but also to preserve his or her confidence in the medical profession and in health services in general (Z v. Finland 1997).

Unwitting breaches of Article 8: a breach of Article 8 can be made unwittingly. The misuse of personal information by a local authority in perfect good faith could be a breach of Article 8. It is not necessary to demonstrate either carelessness or bad faith for there to be liability under the Human
Rights Act. Mistaken judgments or assessments by professionals do not per se render childcare measures incompatible with the requirements of Article 8. Authorities have duties to protect children but they cannot be held liable every time genuine and reasonable concerns about the safety of children with regard to members of their families are proved, retrospectively, to have been misguided.

Duty of care: when parents are suspected of abusing their child(ren), case law has established that health professionals do not owe a commonlaw duty of care to parents. The duty of care is only to the child.

Care orders: the mutual enjoyment by parent and child of each other's company constitutes a fundamental element of family life. Domestic measures hindering such enjoyment amount to an interference with the right protected by Article 8 . Placing children into care will inevitably interfere with the rights of both parents and children under Article 8(1) to enjoy respect for their family life. Whether it breaches Article 8 will depend on justification or not under Article 8(2).

Care order process: in cases where children may be assessed as being at risk from parents and are placed into care, Article 8 places a duty on local authorities to involve parents appropriately in decisions affecting their children's care. Parents should be involved in the decision-making process to a degree sufficient to provide them with the requisite protection of their interests. Parents must also be able to obtain access to information that is relied upon by the authorities when taking protective measures in connection with their child.

Emergency care orders: there may be circumstances when a child has to be removed in an emergency without involving his or her parents in the decision-making process. The State must be able to demonstrate that such a measure was necessary, that a careful assessment of the effect of the proposed measure on both parents and child had been made, and that possible alternatives had been considered.

Margin of appreciation and care orders: the margin of appreciation to be accorded to national authorities will vary in the light of the nature of the issues and the seriousness of the interests at stake, i.e. interplay with the concept of proportionality. Authorities enjoy a wide margin of appreciation in assessing the necessity of taking a child into care. However, a stricter scrutiny is called for in respect of any further limitations, such as restrictions placed by those authorities on parental rights of access, and of any legal safeguards designed to secure an effective protection of the right of parents and children to respect for their family life.

Family reunification and positive measures: Article 8 encompasses a positive duty to facilitate family reunification. Failure to uphold this duty may lead to a breach of Article 8. Where the existence of family relations based on genetic descent or on existing emotional ties has been established Article 8 includes a parent's right to the taking of measures with a view to his or her being reunited with the child (and an obligation on the national authorities to facilitate such action). The obligation on the national authorities to take such measures is not absolute - even in the case of family relations based on genetic descent - especially where the parent and child are still strangers to one another. The nature and extent of such measures will depend on the circumstances of each case, but the understanding and cooperation of all concerned will always be an important ingredient. 


\section{References}

Curtice M (2009) Article 8 of the Human Rights Act 1998: implications for clinical practice. Advances in Psychiatric Treatment 15: 23-31.

Department of Health (2008) Mental Health Act 1983. Code of Practice. TSO (The Stationery Office).

HM Government (2004) Every Child Matters. Change for Children. Department for Education and Skills.

HM Government (2007) The Consolidated 3rd and 4th Periodic Report to the UN Committee on the Rights of the Child: UK Government. Department for Children, Schools and Families.

A local authority v. (1) A health authority (2) Ms A [2003] EWHC 2746 (Fam).

Andersson v. Sweden (1992) ECtHR Application no. 12963/87 20th January.

Bury Metropolitan Borough Council v. D [2009] EWHC 446 (Fam).

Elsholz v. Germany (2000) ECtHR Application no. 25735/94 13th July.

Glass v. United Kingdom (2004) ECtHR (Merits) Application no. 61827/00 9th March.

(1) Ingo Kutzner (2) Annette Kutzner v. Germany (2002) 35 EHRR 25.

JD (FC) (Appellant) v. East Berkshire Community Health NHS Trust and others (Respondents) and two other actions (FC) [2005] UKHL 23

London Borough of Brent v. (1) Mr and Mrs N, the minor's foster carers and (2) $P$, a minor (appearing by Pauline Bennett, her Guardian) [2005] EWHC 1676 (Fam).

Mrs Stephanie Lawrence v. Pembrokeshire County Council[2006] EWHC 1029 QB

Nielsen v. Denmark (1988) 11 EHRR 175 28th November.

$R$ (on the application of Sue Axon) v. The Secretary of State for Health and The Family Planning Association (Intervenor) [2006] EWHC 37 Admin.
$R$ (on the application of TB) $v$. The Combined Court at Stafford and (1) The Crown Prosecution Service and (2) South Staffordshire Healthcare NHS Trust (interested parties) [2006] EWHC 1645 Admin.

Re A (Children), sub nom Re A (Conjoined twins: medical treatment), sub nom Re A (Children) (Conjoined twins: surgical separation) (2000) CA (Civ Div) 22nd September.

Re C (A child) [2007] EWCA Civ 2.

Re C \& F (Children) [2003] EWHC 1376 (Fam).

Re $R$ (A child) [2003] EWCA Civ 182: [2003] (Fam) 129; [2003] 2 All ER 131.

RK and AK v. The United Kingdom (2008) ECtHR Application no. 38000(1)/05 30th December.

Samuel $R$ (by his Grandmother and Litigation Friend June Margaret D) v. W Primary Care Trust [2004] EWHC 2085 (Fam).

Sheffield City Council v. (1) S (by his litigation friend the Official Solicitor) (2) DS [2002] EWHC 2278 (Fam), [2003] 1 FLR 292

Treharne \& Ors v. Secretary of State for Work and Pensions [2008] EWHC 3222 (QB).

TP and KM v. The United Kingdom (2001) ECtHR (Merits) Application no. 28945/95 10th May.

Venema v. The Netherlands (2002) ECtHR (Merits) Application no. 35731/97 17th December.

Vo v. France (2004) ECtHR Application no. 53924/00 8th July.

W v. (1) Westminster City Council (2) Anca Marks (3) James Thomas [2005] EWHC 102 (QB).

Yousef v. The Netherlands (2002) ECtHR (Merits) Application no. 33711/96 5th November; 3 FCR 577.

Z County Council v. (1) TS (2) DS (3) ES (4) A [2008] EWHC 1773 (Fam).

Z v Finland (1997) 25 EHRR 371

\section{MCQs}

Select the single best option for each question stem

1 Regarding Article 8 of the Human Rights Act 1998 the following is true:

a it is an absolute right

b it only applies to adults

c any interference does not need to be in accordance with law

d it provides for the right to private life

e it provides for the right to a social life.

2 The court has found that the essence of family life does not include:

a love

b trust

c confidence

d mutual dependence

e constrained social intercourse.

3 Regarding family life, private life and Article 8 the following is true:

a family life ceases once a child reaches the age of majority

b family life will always flow from genetic parenthood c family life will not flow from looking after a child to whom one is not related by blood

d private life and family life will not come into conflict

e where there is neither a genetic link nor a personal relationship of a family nature, there is no family life to respect.

4 With regard to Article 8 and children being placed into care:

a case law has established that when parents are suspected of abusing their children, health professionals owe a duty of care to parents as well as the child

b placing a child into care will only interfere with the Article 8 rights of the child

c the duty of care to the child does not prevail over that of the parents

$d$ care orders that hinder the enjoyment of family life will not amount to an interference with the right protected by Article 8

e placing children into care will inevitably interfere with the rights of both parents and children under Article 8(1). Whether this breaches Article 8 will depend on justification or not under Article 8(2)
5 There may be circumstances when a child has to be removed into care in an emergency. Regarding Article 8 case law and emergency care orders the following is correct:

a the State does not need to demonstrate that such a measure was genuinely necessary

b the State must be able to demonstrate that a careful assessment of the effect of the proposed measure for only the child had been made

c the State does not need to demonstrate that possible alternatives had been considered

$d$ there may be circumstances when a child has to be removed in an emergency without involving his or her parents in the decision-making process

e the State must be able to demonstrate that a careful assessment of the effect of the proposed measure for only the parents has been made. 